\title{
The Mediation Effect of Environmental Performance on Gender Diversity at Financial Performance Evidence From Indonesia
}

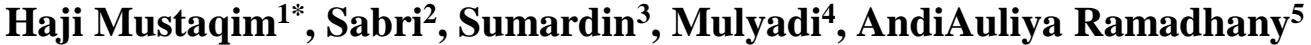 \\ 1,2,3,4,5 UniversitasIbnuSina, Batam,Indonesia \\ ${ }^{1}$ ms.syurah@gmail.com
}

\begin{abstract}
The purpose of this paper is to determine the direct influence gender diversity on financial performance as well as through environmental performance as a mediating variable Design/methodology/approach : The data used ini this research are secondary data involving 110 companies listed on the Indonesia Stock Exchange for period 2012-2018. The data used in this study were analyzed using partial least square and carried out with help of software WarpPLS 6.0 Finding: The results show that the gender diversity on impact financial performance. Originality/value: The result also show partial mediation of environmental performance on impact gender diversity on financial performance.
\end{abstract}

Keywords

Environmental Performance, Gender Diversity, Financial Performance

Article Received: 10 August 2020, Revised: 25 October 2020, Accepted: 18 November 2020

\section{Introduction}

Financial performance is a major factor for the survival of the company. This is because all company business processes require financial support and the results of business processes in the form of profit. Financial performance is used as a decision for investors. The financial performance of the company increases because of the roles and responsibilities of the board of directors, both men and women who have worked optimally. The executive board plays an important role in making investment decisions of the company. The CEO as a decision controller must prioritize rationality in investment decision making, in addition to the emotional and psychological factors of the $\mathrm{CEO}[1][2]$.

One of the most widely studied executive board diversity is gender diversity (Pasaribu et al., 2019). Diversity is expected to be able to produce decisions objectively and comprehensively from different points of view Pilar and Joaquina). Seiersad revealed the existence of female directors is needed in two circumstances, (1) the company's business case (2), and Court case. Pasaribu et al. (2019) revealed that gender diversity was emphasized on the composition of women either as a board of directors or a board of commissioners[3].
The participation of female directors in developed countries is by enacting regulations and laws. The Norwegian government controversially passed a law for female directors of $40 \%$ in [4]. The French government, the composition of female directors for large companies in 2014 by $20 \%$ increased to $40 \%$ in 2017[5]. The Italian government imposes 33\% composition of female directors, otherwise the company is fined 1 million Euro. Not only in the EU, the desire of Japan is targeting $30 \%$ representation of female directors for senior positions by 2020. Malaysia and Brazil also set $30 \%$ and $40 \%$ for the composition of female directors (The Economist. The results of a World Bank survey show that the percentage of total ownership of companies by women is $22.1 \%$ of $39 \%$ coming from large-scale companies. This figure shows that women have a positive contribution to economic growth[6].

The study of the World Economic Forum (WEF), revealed that Indonesian women were able to increase economic growth in 2017 by US \$ 5.3 trillion. The perceived benefits of female directors in a company can provide a different perspective in business decision making compared to men. The gentle nature of women is not suitable in a work environment that demands speed, accuracy and firmness in making investment decisions to save companies from investment decision mistakes. 
Gender diversity in Indonesia is interesting to study, because there is still the assumption that men are more suitable to occupy positions in companies[7].

The study revealed an increase in the number of female directors in various countries. PuchetaMartines, Bel-Oms, \& Olcina-Semper, the results of a literary review revealed that there was an increase in female directors in Italy in 2012-2013 by $22.69 \%$, Portugal in $2010-2012$ by $3.8 \%$, Spain in 2008- 2012 at $13 \%$, Peru at $6 \%$, Mexico at $5.1 \%$ and Chile at 3.2\% (Solimene et al., 2017; Terjesen, et al. Solimene et al. revealed an increase in the number of female directors on the Milan Stock Exchange from $6.61 \%$ to $22.69 \%$. The same thing happened in the Portuguese Stock Exchange, the proportion of female directors was 3.8\%[8].

Stakeholder theory can assist managers in determining the need to improve company performance. The diversity of women as executive boards can improve company performance (Campbell \& Vera, 2010; Lückerath-Rovers; Hernandez et al. Positive influence caused by several things, namely (1). The market reacts positively to the long-term development of the company (Campbell \& Vera, 2010). (2). Establishing a good relationship between female CEOs and employees can improve teamwork and maintain good relations with all stakeholders (Dewi \& Dewi, 2016; Lückerath-Rovers, 2013). (3), increasing in the number of female CEO will reduce information asymmetry. (4), reducing loan rates so that the risk of bankruptcy is low in non-public entities. Several studies have revealed that gender diversity has a positive effect on company performance, because female directors enhance connections among all stakeholders at all levels of the company, enhance company reputation and increase company value, a female director has a negative effect on company performance[9][10].

The inconsistency of the results of previous studies is because researchers use different perspectives in developing theories about the effect of gender diversity on financial performance. Govindarajan, stated that the inconsistency of research results is due to other contingency factors. The contingency approach confirms the possibility of other variables that can act as mediating factors that influence the relationship between independent and dependent variables[11].

Contingency theory is used in this study, because the concept of contingency theory explains that the design of an organization will be effective and can be applied universally only under certain conditions. The conditions of an organization are different, so the organizational design is different too. Organizational design is only fit for certain conditions. Implementation of gender diversity is very dependent on contingency variables as explained in contingency theory. The use of contingency theory motivates researchers to identify conditions that are fit for a particular organizational design and develop theories that support it. Therefore, from a number of empirical studies related to contingency theory, this study uses environmental performance as a mediating variable to the best of researchers' knowledge, which has never been studied before[12][13].

Companies that pollute the environment are considered not to have good environmental performance. Good environmental performance can give stakeholders confidence. Environmental performance also reflects how much the company's efforts in carrying out its responsibilities to the environment[14]. To assess environmental performance, the government through the Ministry of Environment since 2002 established a PROPER or a Company Performance Rating Assessment Program in Environmental Management. The company's environmental performance ranking is divided into 5 color ratings ranging from the best gold, green, blue, red, to the worst black. However, during the 16 years of PROPER, the results were not as expected because there were several companies that still obtained red and black ratings. PROPER in the 2012-2018 assessment amounted to 9560 companies with 16 companies whose ranks were not announced due to undergoing legal proceedings and 18 companies not operating again (closed). For details of the rankings namely the gold rank of 66 companies $(0.71 \%)$, the green rank of 2121 companies $(22.26 \%)$, the blue rank of 6605 companies $(69.33 \%)$, the red ranking of 669 companies $(7.02 \%)$, and the black ranking of 65 company $(0.68 \%)$. Companies are considered as winners if they have the ability to manage a green environment in business competition. 
The presence of women directors brings positive results on financial performance, possibly due to: First, previous research on female executive directors largely focused on developing countries such as the US and European Union countries whose composition has been regulated in regulations and laws. This indicates that companies registered in these countries may face certain pressure in effectively forming the composition of the board[15]. Liu et al. (2014) and Mersland (2014), revealed that female directors can significantly improve company performance for developing countries. Second, research related to environmental performance in Indonesia has not been maximally conducted, because the disclosure of environmental performance in the annual report is voluntary. This causes many companies that have not paid attention to the environment due to industrial operations, thereby increasing the burden on the company[16].

\section{Research Methods}

This type of research is quantitative with the association research method. Association research aims to determine the effect of cause and effect between variables.

\section{Variable identification}

The identification of variables is shown in Table 1

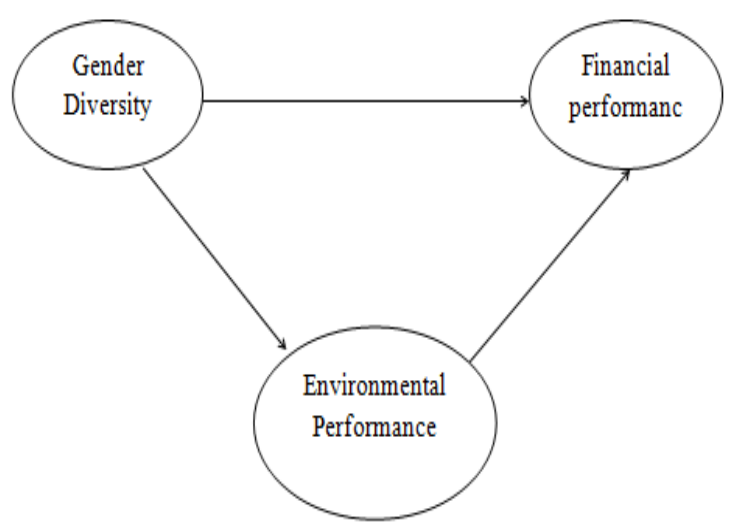

Figure 1.Conceptual framework

\section{Types of research}

Table 1. Variable Identification

\begin{tabular}{llll}
\hline Hypothesis & Independent variable & Mediation variable & Dependent variable \\
\hline H1 & GD & - & FP \\
H2 & GD & KL & FP
\end{tabular}

\section{Operational Definitions and Measurement Variables}

\section{Gender divesity}

Gender diversity is a characteristic that distinguishes between men and women biologically, behavior, mentality and social culture. Measurement of gender diversity in this study is measured by the number of female board of directors owned by a company.

$$
\begin{aligned}
& G D_{i . t} \\
& =\text { Number of Women Board of Directors } \\
& i, t
\end{aligned}
$$

\section{Environmental performance}

Environmental performance is the company's efforts to preserve the environment in which the company operates as a form of responsibility for the company's operational activities. Proxy of environmental performance using PROPER consists of: Gold $=$ value 5, Green $=$ value 4, Blue $=$ value 3 , Red $=$ value 2 and Black $=$ value 1

\section{Financial performance}

Financial performance is a picture of the condition of a company that is analyzed by financial analysis tools. Financial performance is measured using profitability ratios (ROA) to determine the extent to which the market assesses the company from various aspects seen by outsiders.

$$
R O A=\frac{\text { Net profit }}{\text { Total Assets }}
$$

\section{Population and Sample}

The populations in this study are all companies except the financial sector which were listed on the 
Indonesia Stock Exchange in 2012-2018. Research samples are companies that publish annual reports and data used in this study are available. The sampling technique is using purposive sampling. This is done to get the number of samples that best represent and fit the criteria determined earlier.Some sample criteria determined in this study are as follows:

1. Companies that issued financial statements for 2012-2018

2. Companies registered and received PROPER ratings for 2012-2018

3. The company issues a complete annual report and can be accessed through the company's website (http://www.idx.co.id) and (http://www.mnlh.go.id)

4. The company published financial statements in 2012-2018 and all variables needed in this study were available

Table 2. Sample Selection Procedure

\begin{tabular}{clc}
\hline No & Company Sample Information & Total \\
\hline 1 & $\begin{array}{l}\text { The company is registered with } \\
\text { IDX and participates in PROPER } \\
\text { at www. Mnlh.go.in 2012-2018 }\end{array}$ & 447 \\
& $\begin{array}{l}\text { except the financial sector } \\
\text { Companies whose financial } \\
\text { statements are incomplete for the }\end{array}$ \\
& $\begin{array}{l}\text { 2012-2018 period } \\
\text { Companies whose data related to } \\
\text { research variables are incomplete }\end{array}$ \\
Company Sample
\end{tabular}

Source: www.idx.go.id, processed data

\section{Analysis Model and Hypothesis Testing}

The model used in this study is partial least square (PLS) and uses two modeling models, namely the outer model to evaluate the measurement model using reflective indicators and the inner model to evaluate the structural model (Ghozali \& Latan, 2014). In the outer model consists of three types. The validity test of processing can be seen from the correlation between the indicator score (component score) with the construct score (outer loading factor) with the outer loading factor criteria value of each indicator greater than 0.70 can be said to be valid (Hair et al., 2014). Sholihin and Ratmono, (2013) explained that in some cases the condition of the outer loading factor below 0.40 must be removed from the model. However, indicators that have an outer loading factor of 0.40-0.70 must be considered to be maintained. Elimination of indicators by loading $0.40-0.70$ is done if the effect of erasing the indicator can increase Average Variance Expected (AVE) and Composite Reliability (CR) above the predetermined lower limit value. The AVE borderline value is 0.50 and CR is 0.70 (Hair et al., 2014; Ghozali \& Latan, 2014).

After measuring the outer model, measurement of the inner model is done to test the relationship between variables using $\mathrm{R}^{2}$. Values of $0.70,0.45$ and 0.25 of $\mathrm{R}^{2}$ indicate that each model is strong, moderate and weak

The design of the hypothesis test was made based on the purpose of the study, namely the hypothesis test to see the effect of independent variables separately. The level of confidence used $\alpha=5 \%=$ 0.05. So:

If $\rho$-vaue is greater than $\alpha(0.05)$, then $\mathrm{H}_{0}=$ accepted and $\mathrm{H}_{\mathrm{a}}=$ rejected

If $\rho$-vaue is less than $\alpha(0.05)$, then $\mathrm{H}_{0}=$ rejected and $\mathrm{H}_{\mathrm{a}}=$ accepted.

There are two types of tests used. First, the direct effect test, which compares the $p$ value (the measurement results of the evaluation model) with the level of significance used or $\mathrm{R}^{2}$. When the $\mathrm{P}$ value generated from the PLS process is greater than the level of significance it has a significant effect and vice versa. Both indirect tests were carried out by simultaneously estimating indirect effects with the PLS SEM triangle model. Mediation is supported, if the path coefficient from the independent variable to the dependent variable after inclusion remains significant and does not change, the mediation hypothesis is not supported; if the value of the path coefficient from the independent variable to the dependent variable after the mediation variable is dropped and remains significant, then the mediation form is partial mediation and if the path coefficient value of the independent variable to the dependent variable after the mediation variable is entered down and becomes insignificant, then mediation is full mediation (Sholihin \& Ratmono, 2013). 
Analysis and Discussion

Descriptive Statistical Analysis
Table 3 shows descriptive statistics consisting of minimum, maximum, mean, mode and standard deviation of the variables studied from the sample company.

Table 3. Descriptive statistics

\begin{tabular}{llllll}
\hline Variable & Min & Max & Mean & Mode & SD \\
\hline GD & 1 & 4 & 1.34 & 1 & 0.78 \\
EP & 3 & 5 & 3.28 & 3 & 0.51 \\
FP & -0.09 & 0.47 & 0.07 & 0.03 & 0.11 \\
\hline
\end{tabular}

Source: data processed, 2019

Based on Table 3 it can be seen that the average GD of the company in the sample is 1.36 , which means that the average female directors in the company are 1. The minimum value is 1 , indicating that the company which is used as a sample of female directors is at least 1 , while the maximum 4 , shows that the company has 4 female directors, namely the 2016 SMCB and the 2016-2018 UNVR. The mean value of 1.36 with SD 0.79 , shows that the average company sampled did not vary.

Table 4. Descriptive Statistics of PROPER

\begin{tabular}{lcc}
\hline Ranks & Frequency & Percentage \\
\hline PROPER of Gold (5) & 7 & 6 \\
PROPER of green (4) & 18 & 16 \\
PROPER of Blue (3) & 87 & 78 \\
PROPER of Red (2) & - & - \\
PROPER of Black (1) & - & - \\
\hline
\end{tabular}

Source: data processed, 2019

Descriptive statistics of PROPER results show that some of the study samples included in the blue ranking, indicated as many as 87 companies from a total of 112 samples over the 7 (seven) years of the study period or by $78 \%$. The sample of companies that got the best rating, namely PROPER of Gold, was much less than 7 out of the total 112 companies that became the research sample or $6 \%$. There are 18 sample companies or $16 \%$ of which get green. There are no companies in the sample that get PROPER of red and PROPER of black; this indicates that the average company in Indonesia has a high awareness of the environment. The companies that received the highest PROPER score of 5 were SMCB and SPMA
Environmental performance in this study uses PROPER issued by the Ministry of Environment. The better PROPER the higher score the company gets. PROPER scores are categorized into five (5) colors. The worst score is 1 (one) for the black rank and the best score is 5 (five) for the Gold rank.
Financial performance in this study was measured by ROA. The average value is 0.07 which means that the average financial performance of the company is 0.07 . The minimum value of -0.09 , indicates that the performance of companies that are the lowest ROA sample - 0.09 is BUMI in 2012. The maximum value of 0.47 , indicates that the highest sample ROA of 0.47 is UNVR in 2018. The mean value of 0.07 with SD 0.11 indicates that the average of companies sampled did not vary.

\section{Model Testing Results Outer Model Testing}

Outer model testing is an evaluation of reflective construct measurement models that are evaluated 
with convergent validity, discriminant validity and reliability testing.

\section{Convergent Validity}

Table 5 . Estimation Results of Combined Outer Loading Factor

\begin{tabular}{ccccccc}
\hline Indicator & FP & GD & FP & $\begin{array}{c}\text { Outer value } \\
\text { loading }\end{array}$ & p-value & Conclusion \\
\hline FP & 1.000 & 0.000 & 0.000 & 0.128 & $<0.001$ & Fulfilled \\
GD & - & -1.000 & 0.000 & 0.147 & $<0.001$ & Fulfilled \\
& 0.000 & & & & & \\
EP & - & -0.000 & 1.000 & 0.071 & $<0.001$ & Fulfilled \\
& 0.000 & & & & & \\
\hline
\end{tabular}

Source: data processed, 2019

Based on Table 5, it can be seen that the entire

Discriminant Validity proxy is feasible to be used as an indicator that can reflect each of the related variables

Table 6. Measurement Estimation Results of Convergent Validity, Composite Variable dan Cronbach Alpha

\begin{tabular}{cccc}
\hline Indicator & AVE & Composite Variable & Cronbach Alpha \\
& & & \\
\hline FP & 1.000 & 1.000 & 1.000 \\
GD & 1.000 & 1.000 & 1.000 \\
EP & 1.000 & 1.000 & 1.000 \\
\hline
\end{tabular}

Source: data processed, 2019

From the results of data processing, it can be concluded that the entire proxy has produced a loading factor value $>0.70$ with AVE value> 0.50 and composite reliability $>0.70$, making it feasible to be a proxy and all variables have met the requirements of convergent validity.

\section{Reliability Test}

Table 7. Comparison factors of each proxy to latent construct with other construct

\begin{tabular}{ccccccc}
\hline Indicator & Loading & & \multicolumn{2}{c}{ Loading Factor to other constructs } & conclusion \\
& & & FP & GD & EP & \\
\hline FP & 0.128 & $>$ & 1.000 & 0.353 & 0.316 & Fulfilled \\
GD & 0.147 & $>$ & 0.353 & 1.000 & 0.206 & Fulfilled \\
EP & 0.071 & $>$ & 0.316 & 0.206 & 1.000 & Fulfilled \\
\hline
\end{tabular}

Source: data processed, 2019

The value of composite reliability and Cronbach alpha on each variable has a value of 1,000 so that it can be said that all variables in this study meet the reliability test criteria, because the value of composite reliability and Cronbach alpha is above 0.70 .

\section{Test of Model Fit}

Table 8. Test result of Model Fit 


\section{Average Path Coefficient $\quad 0.294 ; \mathrm{P} \leq 0.001$ \\ (APC) \\ Average R-Squared (ARS) $\quad 0.155 ; \mathrm{P}=0.062$ \\ Average Block Variance \\ 1.028 \\ Inflation Factor (AVIF)}

Source: data processed, 2019

Based on the results of data processing Table 8 , shows that this study is said to be fit. Table 8 can be seen that APC and ARS have a value of $\rho$-value $\leq$ 0.10 and an AVIF value $\leq 3.3$ which indicate that there is no multicollinearity problem between proxies and variables

\section{Test of Inner Model}

Table 9. Test Result of Inner Model

\begin{tabular}{ccc}
\hline Variable & $\begin{array}{c}\text { Value of Adjusted } \\
\text { Square }\end{array}$ & $\begin{array}{c}\text { Value of Q } \\
\text { Suare }\end{array}$ \\
\hline FP & 0.262 & 0.294 \\
EP & 0.048 & 0.108 \\
\hline
\end{tabular}

Source: data processed, 2019
Measurement of inner model can be seen from Table 9 adjusted R Square values by considering the value of Q Square. Financial performance or ROA has an adjusted R2 of 0.262 or $26.2 \%$. This shows that gender diversity is able to explain the company's financial performance of 26.2 while the rest is explained by other variables that are not present in this study. Environmental performance or PROPER has an adjusted R2 value of 0.048 or $4.8 \%$. This shows that gender diversity is able to explain the company's environmental performance by 4.8 while the rest are explained by other variables not included in this study. Q Square value indicates that the independent variable in the study of gender diversity has good predictive validity, because the value of Q-Square> 0

\section{Discussion}

Table 10. Mediation Effect

Panel A Direct Effects

\begin{tabular}{lll}
\hline Variable & \multicolumn{1}{l}{ To the path } \\
Gender Diversity & Financial performance & \\
$\mathrm{R}^{2}$ & $0.44(<0.01)$ & \\
\hline Panel B Indirect effects / mediation (path coefficient, $\rho$ value and $\left.\mathrm{R}^{2}\right)$ \\
\hline Variable & To the path & \\
\cline { 2 - 3 } & Environmental & Financial \\
& Performance & performance \\
Gender Diversity & $0.22(<0.01)$ & $0.39(<0.01)$ \\
Environmental Performance & & $0.27(0.02)$ \\
$\mathrm{R}^{2}$ & 0.248 & 0.039 \\
\hline
\end{tabular}

Source: data processed, 2019

Description: $* * * \rho<0.01, * * \rho<0.05,{ }^{*} \rho<0.10$

\section{Effects of Gender Diversity and Financial Performance}

The effect of gender diversity on financial performance shows a positive and significant influence with the value $\beta=0.44$. The results of this study indicate that the more diverse board owned by a company, it will improve financial performance. Charles et al. (2018), stated that gender diversity can improve corporate financial performance. Ernst and Young (2010), stated that the more gender diversity a company has, the more effective and efficient decisions will be made besides helping the company improve corporate governance and corporate value (Adams \& Ferreira, 2009; Campbell $\&$ Vera, 2008). The results of this study are not 
consistent with research conducted by Ionascu et al. (2018). Carter et al., (2010), Weng et al., (2015) Darmadi, (2011), stated gender diversity does not affect financial performance.

\section{The Role of Environmental Performance in Mediating the Effect of Gender Diversity on Financial Performance}

The results showed that environmental performance mediated the effect of gender diversity on financial performance. GD has an effect on financial performance because the number of female directors has always increased in several companies. The influence of GD on environmental performance indicates that environmental performance is related to the presence of women directors who are more concerned about the environment (Pinar et al., 2009; Lee-kuen et al., 2017; Lu \& Herremans, 2019). Contingency theory in a harmonious environment, the board of directors is favored by employees in assigning tasks according to their respective responsibilities ( $\mathrm{Li} \&$ Chen, 2018). These results are consistent (Pinar et al., 2009; Lee-kuen et al., 2017; Li \& Chen, 2018; Lu \& Herremans, 2019).

\section{Conclusion}

Empirical test results indicate that gender diversity is needed in every company. Gender diversity information will be used by investors to see the existence of gender diversity in providing a positive impact on companies on environmental performance and financial performance. The conclusions described above are supported by the following findings:

1. Test results show that Gender diversity has a positive and significant effect on financial performance

2. The test results show that environmental performance variables are able to mediate the partial influence of gender diversity on financial performance, meaning that gender diversity cannot directly affect financial performance but must go through environmental performance

\section{Research Limitations}

This study has limitations that cannot be avoided. Disclosure of limitations has a goal that further research can fill the blank space which is the limitation of this study:

1. The measure of environmental performance in this study only uses PROPER issued by the Ministry of Environment that does not combine other environmental performance measurements such as ISO 14001 and the green industry award issued by the Indonesian Ministry of Industry.

2. The measure of gender diversity in this study only uses female directors without involving the directors of the commissioners.

\section{References}

[1] M. J. J. Lin and C. H. Chang, "The positive effect of green relationship learning on green innovation performance: The mediation effect of corporate environmental ethics," PICMET Portl. Int. Cent. Manag. Eng. Technol. Proc., pp. 2341-2348, 2009, doi: 10.1109/PICMET.2009.5261824.

[2] R. C. Grifoni, M. F. Ottone, and E. Prenna, "Tomographic environmental sections for environmental mitigation devices in historical centers," Energies, vol. 10, no. 3, 2017, doi: 10.3390/en10030351.

[3] S. J. G. Ahn, J. Bostick, E. Ogle, K. L. Nowak, K. T. McGillicuddy, and J. N. Bailenson, "Experiencing Nature: Embodying Animals in Immersive Virtual Environments Increases Inclusion of Nature in Self and Involvement With Nature," $J$. Comput. Commun., vol. 21, no. 6, pp. 399419, 2016, doi: 10.1111/jcc4.12173.

[4] C. H. Chang, "The effect of corporate environmental commitment on green product innovation," 2012 Proc. Portl. Int. Cent. Manag. Eng. Technol. Technol. Manag. Emerg. Technol. PICMET'12, pp. 1144-1151, 2012.

[5] Y. S. Chen and C. H. Chang, "The influences of green perceived quality and green brand awareness on green brand equity: The mediation effect of green perceived risk," 2012 Proc. Portl. Int. Cent. Manag. Eng. Technol. Technol. Manag. Emerg. Technol. PICMET'12, pp. 11521159, 2012. 
[6] M. Hurt, A. Patel, S. Wu, and G. Learmonth, "An Exploration and Characterization of Financial Performance of Standard and Poor's 500 Index Constituents Led by Female CEOs," 2020 Syst. Inf. Eng. Des. Symp. SIEDS 2020, pp. 1-6, 2020, doi: 10.1109/SIEDS49339.2020.9106678.

[7] T. Zhu, "Gender diversity and entrepreneurship," 2019 IEEE Int. Symp. Innov. Entrep. TEMS-ISIE 2019, 2019, doi: 10.1109/TEMS-ISIE46312.2019.9074229.

[8] H. U. Rahman, M. Y. Ibrahim, and A. C. Ahmad, "The impact of soft regulations on boardroom diversity and shareholders' confidence in Malaysia," 2nd Int. Symp. Technol. Manag. Emerg. Technol. ISTMET 2015 - Proceeding, pp. 345-349, 2015, doi: 10.1109/ISTMET.2015.7359056.

[9] R. Hassan, M. Marimuthu, and S. K. Johl, "Demographic diversity and firm value: A review on large companies using panel data approach," 2nd Int. Symp. Technol. Manag. Emerg. Technol. ISTMET 2015 Proceeding, pp. 197-201, 2015, doi: 10.1109/ISTMET.2015.7359028.

[10] B. Hartono, V. S. Ramadhani, Y. Ratnadilla, N. Indarti, and K. H. Chai, "Knowledge management maturity and organizational performance in project-based organizations: Initial evidence from Indonesia," IEEE Int. Conf. Ind. Eng. Eng. Manag., vol. 2016January, pp. 656-660, 2016, doi: 10.1109/IEEM.2015.7385729.

[11] I. Wahyuningsih and M. S. Nurzaman, "Islamic Financial Instruments and Economic Growth; An Evidence from Indonesia," 2020 6th IEEE Int. Conf. Inf. Manag. ICIM 2020, pp. 46-50, 2020, doi: 10.1109/ICIM49319.2020.244668.

[12] R. Indriartiningtias, B. Hartono, and Subagyo, "The Effect of Owner Creativity on Organizational Creativity: Empirical Evidence from Surakarta Indonesia," IEEE Int. Conf. Ind. Eng. Eng. Manag., vol. 2019December, pp. 473-476, 2019, doi: 10.1109/IEEM.2018.8607703.

[13] B. Hartono, S. R. Sulistyo, K. H. Chai, and N. Indarti, "Effective knowledge management strategy and firm's size:
Evidence from Indonesia construction firms," IEEE Int. Conf. Ind. Eng. Eng. Manag., vol. 2017-December, no. 2, pp. 681-685, 2018, doi: 10.1109/IEEM.2017.8289977.

[14] X. Li, "R\&D Intensity and firm performance: Evidence from Chinese manufacturing firms," 2012 IEEE 6th Int. Conf. Manag. Innov. Technol. ICMIT 2012, pp. 45-50, 2012, doi: 10.1109/ICMIT.2012.6225777.

[15] D. E. Padilla, R. Brinkworth, and M. D. McDonnell, "Performance of a hierarchical temporal memory network in noisy sequence learning," Proceeding - IEEE Cybern. 2013 IEEE Int. Conf. Comput. Intell. Cybern., pp. 45-51, 2013, doi: 10.1109/CyberneticsCom.2013.6865779.

[16] S. Leavy, "Gender bias in artificial intelligence: The need for diversity and gender theory in machine learning," Proc. Int. Conf. Softw. Eng., pp. 14-16, 2018, doi: 10.1145/3195570.3195580. 